\title{
Desain Interior Budget Hotel untuk Backpacker dengan Konsep Persahabatan Asia
}

\author{
Fajar Nuur Alfie Rahma dan Thomas Ari K \\ Departemen Desain Interior, Fakultas Teknik Sipil dan Perencanaan, Institut Teknologi Sepuluh Nopember (ITS) \\ e-mail: Thomasjawa@prodes.its.ac.id
}

\begin{abstract}
Abstrak-Desain interior hotel merupakan salah satu disiplin yang bertumpu pada penciptaan sebuah lingkungan dimana para tamu disambut dan disediakan fasilitas untuk beristirahat dan bersantai. Saat ini kebutuhan akomodasi yang praktis dan murah bagi para wisatawan yang melakukan liburan semakin meningkat. Hal ini dikarenakan semakin banyaknya wisatawan lokal maupun mancanegara yang melakukan perjalanan dengan cara backpacker. Budget hotel merupakan jenis tempat menginap yang relatif lebih murah dan menyediakan fasilitas yang digunakan secara bersamaan oleh seluruh penghuni. Pengambilan konsep persahabatan ini sesuai dengan prinsip pendirian budget hotel, yaitu lebih mengedepankan prinsip saling bersosialisasi antar sesama. Konsep ini diciptakan agar sosialisasi dapat terlaksana dengan nyaman dan hangat. Pengaplikasian konsep terletak pada furnitur dan penataan layout ruang. Sedangkan tema Asia dipilih karena menciptakan kesan interior yang hangat. Dan juga menampilkan ciri-ciri khas beberapa negara Asia namun dengan bentukan yang modern. Sehingga pengumpulan karakteristik tersebut dapat membantu menonjolkan konsep persahabatan yang diambil. Pengaplikasian ciri khas Asia yang kuat dapat dilihat dari budaya makan di negara Jepang yaitu lesehan. Namun agar lebih modern, kursi untuk lesehan didesain dengan dudukan tanpa alas kaki. Selain itu, ciri khas lainnya yang digunakan ialah motif kerawangan, plafon lengkung khas Arab, lantai tegel dan motif kawung khas Indonesia. Untuk memunculkan kesan Indonesia yang kuat yaitu dengan memayoritaskan bentuk kawung pada beberapa area. Pengaplikasian ciri-ciri khas beberapa negara Asia yang dipilih menggunakan bentukan yang lebih modern, sehingga nuansa interior ruang terlihat lebih bersih.
\end{abstract}

Kata Kunci-Desain Interior, Budget Hotel, Backpacker, Konsep.

\section{PENDAHULUAN}

I NDUSTRI perhotelan adalah industri jasa yang memadukan antara produk dan layanan. Desain bangunan, interior dan eksterior kamar hotel serta restoran, suasana yang tercipta di dalam kamar hotel, restoran serta makanan dan minuman yang dijual beserta keseluruhan fasilitas yang ada merupakan contoh produk yang dijual. Sedangkan layanan yang dijual adalah keramah-tamahan dan ketrampilan staff/karyawan hotel dalam melayani pelanggannya.

Desain hotel merupakan salah satu disiplin yang bertumpu pada penciptaan sebuah lingkungan dimana para tamu disambut dan disediakan fasilitas untuk beristirahat dan bersantai. Fitur desain yang harus diperhatikan dalam mendesain suatu hotel diantaranya, warna, pencahayaan, material, kegunaan ruang, serta kegunaan perabot dan objek interior.

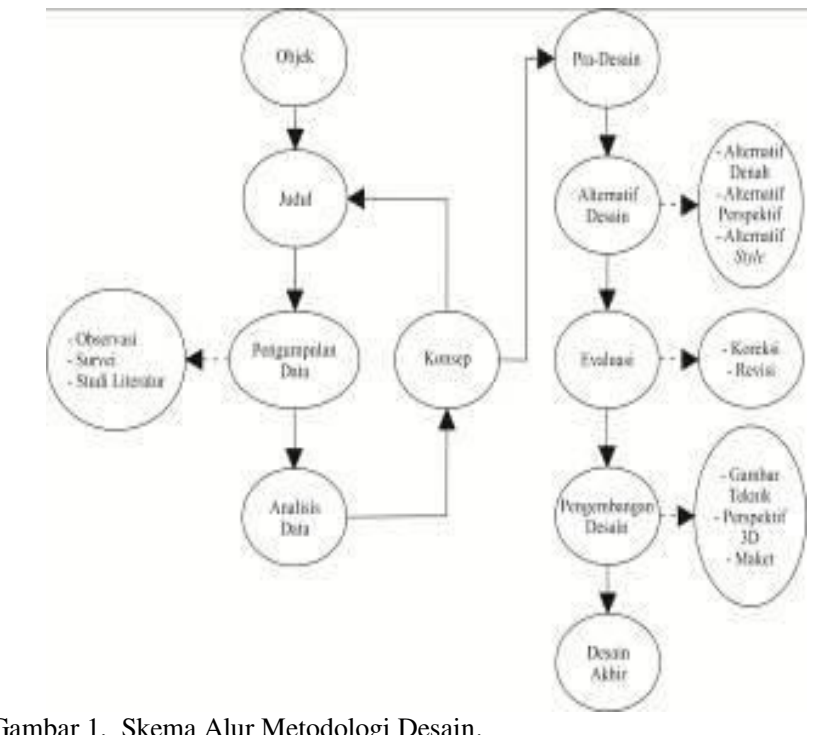

Gambar 1. Skema Alur Metodologi Desain.

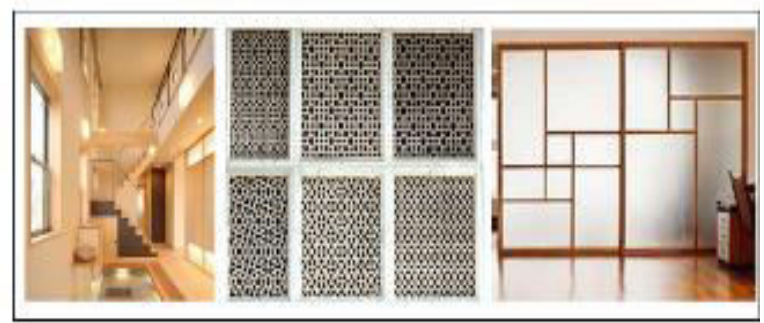

Gambar 2. Konsep Mikro Dinding.

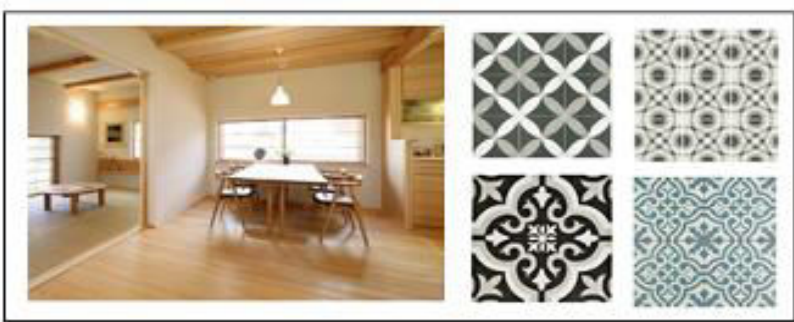

Gambar 3. Konsep Mikro Lantai.

Saat ini, semakin banyak wisatawan lokal maupun mancanegara yang melakukan perjalanan dengan cara backapcker. Backapcker mempunyai daya tarik untuk memiliki kenikmatan hedonic dalam pengalaman dan memenuhi kepuasan diri dengan keadaan yang sederhana (dan terjangkau). Sehingga menimbulkan trend wisata hemat semakin diminati masyarakat. 


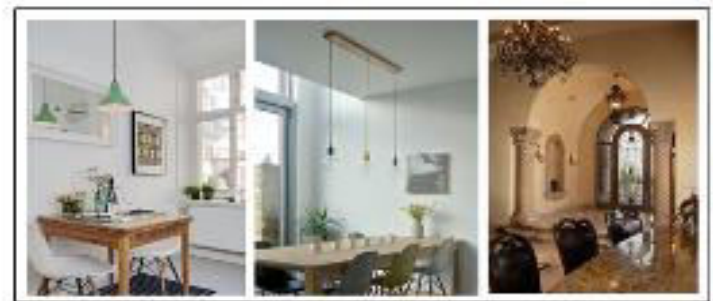

Gambar 4. Konsep Mikro Plafon.

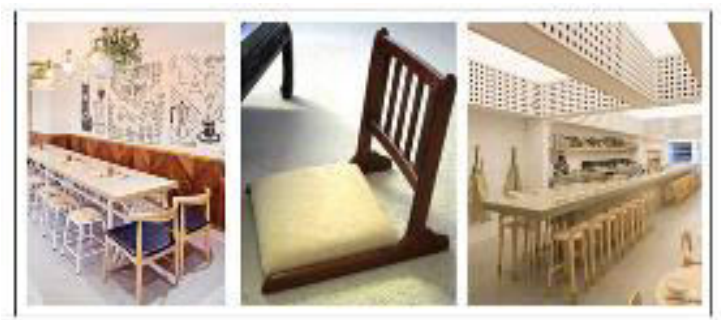

Gambar 5. Konsep Mikro Furnitur.

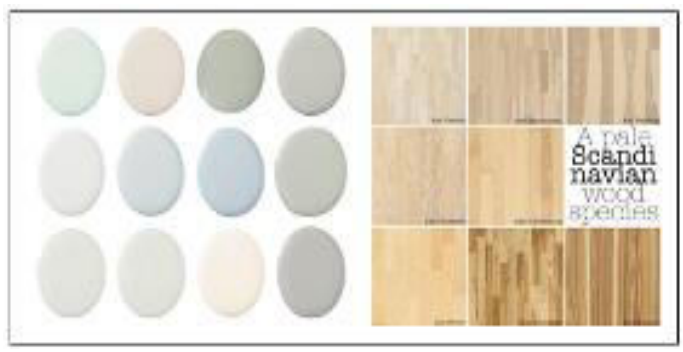

Gambar 6. Konsep Mikro Warna.

Ditinjau dari peningkatan wisatawan dan juga peminat budget hotel, dapat ditarik kesimpulan bahwa dalam satu hotel akan berkumpul wisatawan dari berbagai macam negara. Sehingga tujuan pengambilan konsep persahabatan ini adalah untuk menimbulkan kesan hangat dan bersahabat antar sesama wisatawan. Dan memunculkan suasana yang nyaman dan interior yang di desain secara baik, karena dinilai dapat mempengaruhi loyalitas pengunjung. Selain itu, umumnya budget hotel lebih mengedepankan prinsip saling bersosialisasi antar sesama.

Latar belakang pengambilan konsep Asia ini dikarenakan banyak wisatawan yang berasal dari Asia dan juga Indonesia merupakan negara Asia. Dengan memberikan suasana khas yang ada agar dapat menunjang kenyamanan para pengunjung dan merasakan berada di Asia. Dengan memberikan kedua suasana interior tersebut, diharapkan dapat memberikan efek yang berkesan pada pengunjung yang datang dan juga memberikan daya tarik bagi para backpacker.

\section{A. Permasalahan}

Meningkatnya angka wisatawan lokal maupun asing dengan metode perjalanan hemat yang umumnya disebut dengan backpacker, menimbulkan pebisnis akomodasi budget hotel bersaing untuk menghadirkan fasilitas yang sesuai dengan kebutuhan backpacker namun dengan harga yang terjangkau bagi para backpacker. Selain harga, yang membedakan budget hotel dengan hotel lainnya adalah ia memiliki prinsip saling bersosialisasi antar sesama. Hal itu berefek pada desain dan layouting pada hotel, sehingga dapat terfungsikan dengan baik

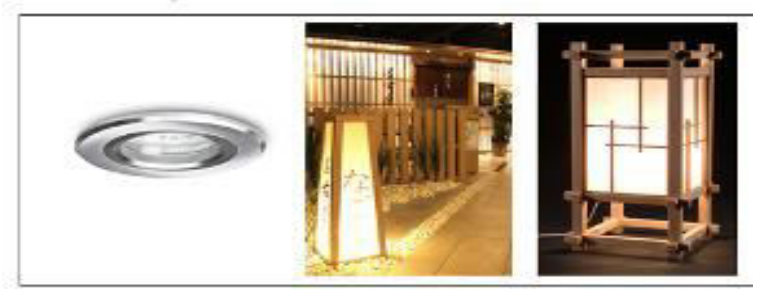

Gambar 7. Konsep Mikro Pencahayaan.

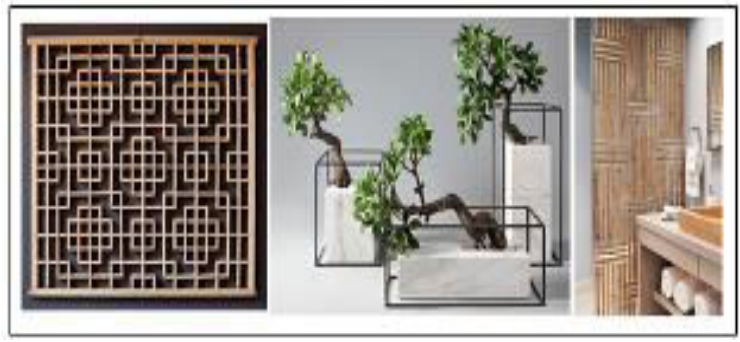

Gambar 8. 3D Desain Area Lobby.

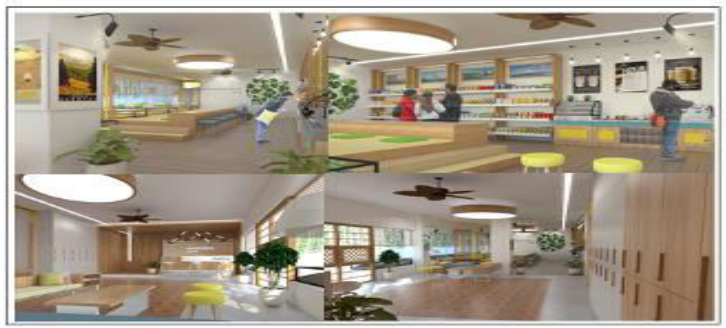

Gambar 9. 3D Desain Area Lobby.

untuk sarana sosialisai dan meningkatkan kepuasan maksimum pada pengunjung yang berkunjung.

\section{B. Tujuan dan Manfaat}

1. Mengangkat konsep baru pada desain interior yang akan diaplikasikan pada objek desain dengan memunculkan karakter backpacker pada budget hotel sesuai dengan prinsip pendiriannya.

2. Menciptakan fasilitas dasar yang sesuai bagi backpacker secara maksimum, sehingga dapat menawarkan harga yang ekonomis namun dengan kualitas yang baik.

\section{Lingkup Desain}

1. Penataan layout ruang.

2. Pengaplikasian elemen interior sesuai dengan konsep.

3. Ruang yang didesain terfokus pada beberapa area terpilih.

\section{URAIAN PENELITIAN}

\section{A. Metode Pengumpulan Data}

Metode descriptive sebagai salah satu bagian dari approach research, dilakukan pada tahap pengumpulan data dan juga penyusunan konsep. Dikarenakan perlu untuk menjelaskan masing-masing unsur objek yang telah didapatkan. Setelah konsep berjalan, tahapan pra-desain sampai dengan desain akhir juga menggunakan metode descrptive untuk menentukan komponen dan elemen desain berdasarkan konsep yang telah dirumuskan sebelumnya.Pengumpulan data dilakukan dalam bentuk observasi, survei, wawancara dan studi literatur. 


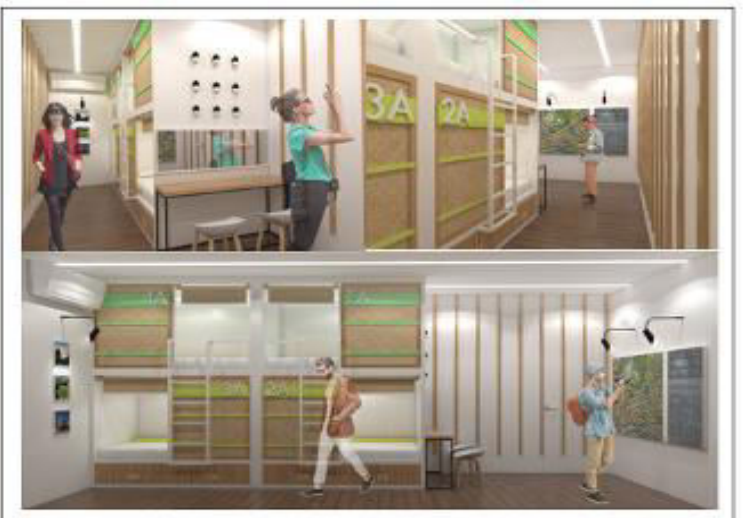

Gambar 10. 3D Desain Area Kamar.

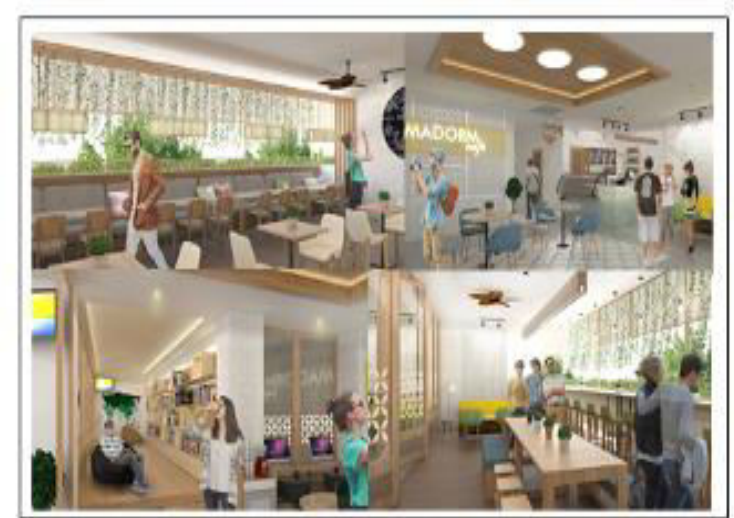

Gambar 11. 3D Desain Area Café.

\section{KONSEP DESAIN}

Studi pustaka merupakan langkah awal dalam metode pengumpulan data. Studi pustaka merupakan metode pengumpulan data yang diarahkan kepada pencarian data dan informasi melalui dokumen-dokumen, baik dokumen tertulis, foto-foto, gambar, maupun dokumen elektronik yang dapat mendukung dalam proses penulisan. Maka dapat dikatakan bahwa studi pustaka dapat memengaruhi kredibilitas hasil perancangan yang dilakukan.

\section{2) Observasi}

Metode observasi adalah metode pengumpulan data yang dilakukan dengan melakukan pengamatan secara sistematis dan pencatatan menurut prosedur tertentu yang hasilnya dapat ditafsirkan secara ilmiah (Nasution, 1992: 123).

Observasi merupakan langkah kedua dalam melakukan pengumpulan data setelah penulis melakukan studi pustaka. Observasi merupakan teknik pengumpulan data dengan cara melakukan pengamatan tentang keadaan yang ada di lapangan. Dengan melakukan observasi, penulis menjadi lebih memahami tentang subyek dan obyek yang sedang diteliti.

3) Wawancara

Wawancara merupakan langkah yang diambil selanjutnya setelah observasi dilakukan. Wawancara atau interview merupakan teknik pengumpulan data dengan cara bertatap muka secara langsung antara pewawancara dengan informan. Wawancara dilakukan jika data yang diperoleh melalui observasi kurang mendalam.

\section{B. Metode Analisis Data}

Data dan kelengkapan yang sudah didapat dari hasil pengumpulan data kemudian dianalisis dengan penggunaan metode deduktif. Metode deduktif ini merupakan metode dimana data yang telah diperoleh dibandingkan dengan desain yang telah ada, kemudian diambil segi positif dan manfaatnya serta memepertimbangkan segi negatifnya.

Selain menggunakan metode deduktif, analisa data ini juga menggunakan metode komperatif. Metode komperatif sendiri adalah metode menggabungkan data untuk membandingkan data-data yang telah didapatkan.

\section{Metode Desain}

Metode desain ditunjukkan pada Gambar 1.

\section{A. Objek Desain}

Objek desain yang diambil pada Tugas Akhir ini adalah Malang Dorm Hostel atau dikenal sebagai Madorm Hostel, Dimana hotel tersebut memeliki ciri khas dan keunikan tersendiri, yaitu fasilitas bunkbed dan sharing-facilities. Dengan segmen pasar umumnya untuk para backpacker yang tidak mementingkan kemewahan.

\section{B. Konsep Makro}

Konsep makro dari perancangan ini adalah mengambil atmosfir akan kebudayaan dan ciri khas dari beberapa negara Asia. Dan juga motif khas Indonesia sebagai identitas Madorm Hostel. Implementasi kebudayaan dan karakteristik Asia ini disesuaikan dengan desain kontemporer atau kekinian. Sumber-sumber ide dari karakteristik khas Asia yang akan diaplikasikan dalam proses perancangan adalah gaya makan lesehan khas Jepang, motif lengkung dari budaya Arab untuk plafon, produk-produk kebudayaan Asia lainnya yaitu batik, lantai tegel dan motif kerawangan yang disederhanakan agar terlihat lebih modernl.

Produk-produk budaya ini sebelum diaplikasikan kedalam interior, akan melalui proses transformasi bentuk baik berupa analogi maupun morfologi. Hasil dari proses transformasi produk-produk kebudayaan ini akan diaplikasikan pada elemen-elemen interior, yaitu dinding, lantai, plafon, furnitur, elemen estetis, dan warna.

\section{Konsep Mikro}

\section{1) Dinding}

Konsep mikro pada dinding objek dengan mengaplikasikan ornamen dan bentukan khas Asia. Peletakan motif tersebut terdapat di berbagai area. Tak hanya motif, dapat juga mengembangkan bentukan tersebut menjadi sebuah elemen estetis untuk ruangan. Motif tersebut terinspirasi dari kerawangan khas dari arsitektural India. Namun disini diolah dengan bentukan yang khas dari beberapa negara. Seperti China yang tidak jauh berbeda dengan India yang khas dengan bentukan bunga atau lengkung, sedangkan Jepang dengan motif geometrisnya. Tak tertinggal, dari Indonesia pun diambil dari batik kawungnya untuk tidak meninggalkan unsur Indonesia. 
Material yang digunakan untuk dinding tersebut adalah material yang bersifat natural dan alami. Warna - warna yang diaplikasikan pun juga menggunakan warna yang netral dan hangat. Selain itu, beberapa area menggunakan mural untuk menambah aksentuasi.

\section{2) Lantai}

Material yang digunakan untuk lantai di setiap ruangan hotel umumnya menggunakan kayu parket. Beberapa area menggunakan bahan vinyl sebagai penambahan aksentuasi pada beberapa sudut. Dan dengan penambahan material alam, seperti batu-batuan di beberapa area sebagai penambah suasana alam dalam ruangan. Untuk area kamar mandi menggunakan lantai bermaterial keramik tile dengan warna soft dan hangat.

Agar memberikan kesan sedikit kuno, pengaplikasian lantai beberapa dengan menggunakan lantai tegel khas indonesia. Namun dengan motif-motif yang lebih modern agar tidak terkesan memaksa. Pengaplikasian lantai ini dapat membuat suasana tidak lagi dingin karena terlalu modern, namun menjadi lebih hangat dan berwarna.

3) Plafon

Konsep plafon secara teknis hanya menggunakan material berbahan gypsum. Dengan warna netral ataupun soft, agar suasana yang terciptakan tetap hangat dan nyaman. Pengoptimalan plafon akan dilakukan pada elemen yang akan teraplikasikan seperti lampu. Lampu-lampu yang digunakan adalah lampu downlight dan juga hanging lamp untuk di beberapa area. Hanging lamp disini menampilkan beberapa bentukan dan ada yang menampilkan karakteristik gaya interior Jepang.

Bentukan plafon ada yang terinspirasi dari gaya interior arab, yaitu dominan dengan bentukan lengkung. Kesan lengkung yang didapat adalah semakin terasa luas dan lapang bagi penggunanya.

4) Furnitur

Sesuai dengan konsep yang diambil yaitu persahabatan, pengaplikasian dalam beberapa furnitur adalah dengan menonjolkan furnitur yang luas dan panjang agar pengunjung dapat ber-sosialisasi antar sesama tanpa rasa canggung dan tidak terbatasi. Dan terkesan memaksa untuk saling berkomunikasi.

Area lesehan pada interior terinspirasi dari budaya Asia umumnya pada Indonesia dan Jepang. Namun agar lebih menonjolkan karakter Jepang, maka pada area lesehan beberapa menggunakan kursi tanpa kaki agar lebih terkesan modern. Sedangkan yang lain tetap mengguunakan bantalan biasa. Untuk material yang digunakan umumnya kayu, MDF, multipleks dan beberapa jati dengan finishing HPL, cat duco, dan juga politur.

5) Warna

Terkait dengan tema ruang, semua tema warna dapat digunakan hanya saja perlu pengaturan dalam intensitas, harmonisasi dan efek psikologis yang ditimbulkan. Harmonisnya komposisi warna didapat dari pemilihan komponen warna yang berasal dari area kroma warna yang sama/ berdekatan. Contoh: krem muda, krem agak tua, putih dan coklat tua sebagai aksen. Hindari komposisi analog ataupun split komplementer. Contoh: komposisi keluarga warna biru dikombinasikan dengan merah dalam intensitas yang sama kuat. (Thomas A. K., 2009).

Suasana yang hangat dan nyaman sangat cocok untuk sebuah budget hotel yang menjunjung sisi solidaritas dan sosisalisai. Karena prinsip pendirian hotel ini berbeda dengan hotel pada umumnya, yang lebih mengedepankan area publik daripada area privat. Sehingga pemilihan warna yang digunakan adalah warna netral dan natural. Agar dapat membawa suasana yang hangat dan nyaman dalam interior.

6) Pencahayaan

Pencahayaan umum yang digunakan adalah pencahayaan buatan seperti downlight. Tingkat penerangan ideal adalah 150 lumen dengan warna cahaya hangat. Dapat dilayani lampu TL, PL, SL warna daylight dalam kompartemen difuser, kombinasi dengan dicroix halogen kekuningan untuk memberi kesan hangat tanpa silau. (Thomas A. K., 2009). Untuk menambahkan kesan asia, menggunakan beberapa model lampu yang memiliki bentukan dan ciri khas Asia. Dengan warna yang hangat dan bahan yang alami.

7) Elemen Estetis

Elemen estetis yang digunakan tidak jauh dari konsep Asia yang diambil. Bentukan dan ciri-ciri khas seperti kerawangan yang khas dari India, namun dengan motif yang terispirasi dari karakter beberapa negara. China dan India yang memiliki karakter tidak jauh berbeda, yaitu dengan motif lengkung menyerupai bunga. Sedangkan Jepang mengedepankan motif geometris karena lebih mengutamakan minimalism ruangan. Untuk memunculkan kesan alam, dengan menambahkan tanaman hias dan memperbanyak bukaan.

\section{DESAIN AKHIR}

\section{A. Ruang Terpilih-Lobby}

Area lobby ini merupakan semi outdoor, namun agar tetap dirasa nyaman maka perbatasan antara area luar dan dalam diberi beberapa pagar kayu kecil dan ditengahnya diberi kaca. Lantai menggunakan motif kayu untuk di area minimarket, pantry dan resepsionis agar suasana menjadi lebih hangat. Untuk area masuk, lounge, hingga pintu masuk ke area dalam hotel memakai lantai acian yang diberi aksen lantai tegel.

Sedangkan untuk area lesehan menggunakan alas tikar rotan bambu seperti di Jepang. Furnitur yang digunakan didesain agar lebih modern, tidak hanya bantalan untuk duduk. Dengan menggunakan kursi pada umumnya namun tidak berkaki agar tidak meninggalkan kesan lesehan.

Pada dinding sisi belakang area resepsionis, menggunakan signage dengan bahan cutting multipleks dengan motif kawung. Pintu masuk utama lobby, mengaplikasian motif kerawangan khas India namun dengan motif yang lebih sederhana dan simpel.

\section{B. Ruang Terpilih-Bunkbed Room}

Berbeda dengan hotel pada umumnya, hostel ini sebagian besar menggunakan model kasur bunkbed. Dengan lahan yang minimal namun tetap bisa menampung banyak pengunjung. Dengan mengusung konsep persahabatan asia, kamar hotel ini didesain sesuai dengan tema tersebut. 
Penggunaan material dan warna tidak banyak macamnya, sehingga ruangan yang sempit pun tidak terlihat sesak. Warna yang diambil adalah warna netral dan hangat. Dengan menggunakan bahan rotan dari bambu, membuat kesan Asia semakin terasa. Karena kerajinan rotan dan material bambu merupakan kerajinan khas dari Asia, terutama Indonesia dan Jepang.Pintu kamuflase pun juga diterapkan di area kamar agar suasana tidak ramai dan tidak terkesan memaksa. Beberapa kayu di dinding diberi jarak dan kemudian dilapisi oleh akrilik putih susu dan dalamnya diberi lampu LED sebagai pencahayaan.

\section{Ruang Terpilih-Cafe}

Area Cafe pada hostel ini merupakan penggabungan konsep ciri khas dari beberapa negara Asia. Penggunaan plafon lengkung terinspirasi dari model arsitektural dari Asia Barat, yaitu Arab. Sehingga menampilkan kesan yang lapang dan mewah.Bentukan kerawangan diambil dari ciri khas arsitektural negara India. Dengan memainkan motif dari beberapa negara, China yang tidak berbeda jauh dengan India yaitu berbentuk bunga dan Jepang dengan motif geometrisnya.

Motif kawung yang diambil merupakan motif khas dari batik Indonesia yang sudah dikenal oleh banyak orang. Pengaplikasiannya tak hanya untuk dinding, namun juga untuk stiker. Meskipun ada beberapa motif dari luar, namun tetap mengedepankan motif dari Indonesia.

Material dan warna tetap terfokus dengan warna yang netral dan hangat. Pengaplikasian lantai tegel yang merupakan ciri khas Indonesia, namun dengan warna yang lebih soft dan motif yang tidak rumit.

Area baca menggunakan lesehan sama halnya seperti area makan pada lobby. Hanya saja pada area cafe menambahkan area lesehan pada bagian outdoor. Dengan memainkan bentukan rumah dan menambahkan unsur Jepang, seperti lampu kertas dengan motif bambu. Menghadirkan bentukan rumah agar lebih terkesan homey dan mengingatkan pada pengguna bahwa desain yang diambil akan membuat pengunjung berada di rumah yang nyaman dan tenang.

\section{KESIMPULAN}

Dalam perancangan Penelitian berjudul "Desain Interior Budget Hotel Untuk Backpacker Dengan Konsep Persahabatan Asia" ini dapat diambil beberapa kesimpulan, diantaranya:
1. Hotel budget merupakan hotel low budget untuk wisatawan terutama para backpacker yang memiliki fasilitas akomodasi yang berbeda dengan hotel pada umumnya.

2. Fasilitas pada hotel budget digunakan untuk bersama, sehingga lebih banyak tempat untuk public space daripada untuk private. Dikarenakan umumnya budget hotel lebih mengedepankan prinsip saling bersosialisasi.

3. Konsep tema Persahabatan Asia pada Hotel merupakan kekuatan untuk menarik calon tamu untuk menggunakan fasilitas-fasilitas hotel dan memiliki misi untuk melestarikan dan mempertahankan kebudayaan Asia terutama Indonesia kepada masyarakat luas baik nasional maupun internasional.

4. Mendesain area yang kecil dan sempit atau minim lahan, diharuskan untuk tidak terlalu memainkan banyak warna yang berat. Sehingga tidak meninggalkan kesan rasa suram atau tertekan bagi penggunanya.

5. Pengambilan konsep yang beragam seperti Asia yang memiliki banyak ciri khas tersendiri, disarankan untuk mengambil ciri yang kuat namun lebih disederhanakan. Tak hanya asal mengambil, namun perlu hati-hati dalam memilih agar banyaknya ciri tersebut dapat menyatu dan seirama.

\section{DAFTAR PUSTAKA}

[1] Rachmaniyah, Nanik. 2016. Studi Langgam Desain Sebagai Dasar Mendesain Hotel. Surabaya.

[2] Ari K., Thomas. 2009. Rancangan Ruang Praktik Yang Nyaman Dari Aspek Desain Interior. Surabaya.

[3] Nasution, S. 1992. Metodologi Penelitian Kualitatif. Bandung: Rema Rosdakarya.

[4] Wardhana, Mahendra. 2013. Bahan Kuliah: Metodologi Riset Interior. Institut Teknologi Sepuluh Nopember. Surabaya.

[5] Panero, Julius ; Zelnik, Martin. 1979. Human Dimension \& Interior Space. Watson-Guptill Publications. New York

[6] Pratama Y., Geiga. 2013. Redesain Hotel Satelit Surabaya dengan Tema Kebudayaan Indonesia Kontemporer. Surabaya: Jurusan Desain Interior Fakultas Teknik Sipil dan Perencanaan Institut Teknologi Sepuluh Nopember.

[7] http://interiordesainadia.blogspot.co.id/2013/03/pengertian-desaininterior.html (15/12/2016, 23.10 WIB)

[8] https://id.wikipedia.org/wiki/Hotel_kapsul (16/12/16, 0.34 wib)

[9] http://interiordesign.id/gaya-desain-interior-dari-8-negara/ (15/06/17, $01.30 \mathrm{wib})$

[10] http://rumahdandesign.com/desain-interior-rumah-asia/ (22/2/17, 22.30 wib)

[11] http://www.dokmanamura.co.id/10-tips-desain-interior-ber-gaya-alaorientalasia-untuk-rumahapartemen/ (22/2/17, 2249 wib) 